\title{
TUAN GURU RETEH SYEKH 'ABDURRAHMAN YA'QUB: Kiprah, Peran, dan Pemikirannya dalam Bidang Pendidikan Islam
}

\author{
Zulkifli M. Nuh \\ Universitas Islam Negeri Sultan Syarif Kasim Riau \\ Email: kamp_guntung@yahoo.co.id \\ Alimuddin Hassan \\ Universitas Islam Negeri Sultan Syarif Kasim Riau \\ Email: alimuddin.hassan240966@gmail.com

\section{Kholil Syu'aib} \\ Universitas Islam Negeri Sultan Syarif Kasim Riau \\ Email: kholil.syuaib@uin-suska.ac.id
}

\begin{abstract}
This paper would like to explain about the gait, role, and thoughts of Tuan Guru Reteh (TGR) Shaykh 'Abdurrahman Ya'qub in the field of Islamic education. This paper is a result of the search for his innovative thinking in developing Islamic education in the area of Indragiri Hilir Riau Province. Based on the results of these searches can be emphasized several things: first, that TGR. Shaykh 'Abdurrahman Ya'qub has a fairly qualified educational background. Second, that TGR. Shaykh 'Abdurrahman Ya'qub has played a very important, major and dual role in the society, especially in the field of education and dakwah even appointed in the administration of government as the formal leader of religion. Third, that TGR. Shaykh 'Abdurrahman includes productive scholars in the birth of written works. Thus, it is very natural and appropriate for TGR. Shaykh 'Abdurrahman Ya'qub is called a scholar who has authoritative, comprehensive and productive religious knowledge in the Malay-Indragiri region in particular, and the archipelago in general. With these considerations, the title as "Ulama Besar Kharismatik Melayu-Indragiri" is very worthy of the TGR. Shaykh 'Abdurrahman Ya'qub.
\end{abstract}

Keywords: 'Abdurrahman Ya'qub, Islamic education, scholar

\section{A. Pendahuluan}

Pada paroh pertama abad ke-20, ada seorang sosok ulama yang juga telah memainkan perang penting, utama dan ganda di pelosok-pelosok wilayah Indragiri Hilir, Riau, tetapi luput dari pengetahuan masyarakat pada umumnya, dan masyarakat 
Zulkifli M. Nuh, Alimuddin Hassan, Kholil Syu'aib: Tuan Guru Reteh...

ilmiah pada khususnya. 'Ulama besar yang telah memainkan peran sebagai pewaris risalah al-nubuwwah itu adalah Tuan Guru Reteh (TGR) Syekh 'Abdurrahman Ya'qub (1912-1970).

TGR. Syekh 'Abdurrahman bin Ya'kub tidak begitu dikenal bukan lantaran kapasitas keilmuan-ulamanya, sebab keilmuan-keulamaannya sangat luas dan mendalam serta mumpuni. Akan tetapi, ia tidak begitu tersohor namanya dibandingkan dengan ulama yang memiliki kapasitas keilmuan sama dengannya, sebut misalnya Tuan Guru 'Abdurahaman Shiddiq juga dari Indragiri, Riau, dikarenakan beberapa hal: pertama, TGR. Syekh Abdurrahman Ya'qub hidup dan berkiprah di pelosok perkampungan terpencil di Kecamatan Reteh, Indragiri, Riau, yaitu di Kota Baru Reteh, Sungai Gergaji dan Pasar Kembang. Kedua, sebagai kelanjutan yang pertama, sehingga konsekuesinya menjadi luput dari perhatian para pengkaji/peneliti. Bahkan sampai saat ini, lebih dari seabad kelahirannya, boleh dikatakan belum/tidak banyak penelitian untuk mengangkat ketokohan TGR. Syekh 'Abdurrahman Ya'qub, kecuali apa yang dilakukan oleh Hajar Hasan dalam menyelesaikan pendidikan Program Doktor (S3) di UIN Sultan Syarif Kasim Riau. ${ }^{1}$ Ketiga, TGR. Syaikh Abdurrahman Ya'qub tidak dapat memaksimalkan peran dan kiprahnya serta pengaruhnya disebabkan keterbatasan usianya yang wafat pada usia 58 tahun (1912-1970).

Kapasitas keilmuan sekaligus keulamaan TGR. Syekh Abdurraham Ya'qub dapat dilihat dari: (a) latar belakang pendidikannya, terutama; (b) kiprah dan perananya di tengah-tengah masyarakat melalui dakwah; (c) kiprah dan perannya mencerdaskan generasi melalui lembaga pendidikan; (d) kiprah dan perannya sebagai pejabat dalam bidang pemerintahan; dan (e) karya-karya tulis (kitab-kitab) yang dihasilkannya. Menelaah dan melihat perjalanan hidup dan kiprah TGR. Syekh 'Abdurrahman Ya'qub dalam mengembangkan ajaran Islam, khususnya dalam dunia pendidikan maka beliau sangat tepat dikatakan seorang ulama yang mempunyai kemampuan dan kesungguhan luar biasa menggeluti dunia pendidikan. Sebagai ulama, TGR. Syekh 'Abdurrahman Ya'qub membimbing dan mengajak umat (khadim al-ummah) mengamalkan ajaran Islam. Kehadirannya sebagai ulama membawa kedamaian dan kesejukan dalam

${ }^{1}$ Untuk itu, penelitian ini akan banyak merujuk, terutama tetang biografi intelektual 'Abdurrahman Ya'quf, kepada hasil penelitian (desertasi) Hajar Hasan tersebut. Lihat, Hajar Hasan, Metode Penetapan Arah Kiblat, Waktu Shalat dan Awal Bulan Qamariyah Menurut H. 'Abdurrahman Ya'qub, Disertasi UIN Sultan Syarif Kasim Riau, 2011. 
masyarakat, karena semua masalah agama yang dihadapi masyarakat dapat diselesaikannya dengan baik. TGR. Syekh 'Abdurrahman Ya'qub sebagai 'ulama besar kharismatik sulit untuk dicari tarannya baik pada masanya maupun pada masa sekarang di Melayu-Riau.

Beralaskan kepada beberapa hal di atas, terutama menyangkut kiprah dan peran TGR. Syekh 'Abdurrahman Ya'qub dalam bidang pendidikan, sembari menyadari bahwa masalah pemikiran pendidikannya tersebut, belum/tidak banyak orang mengkajinya. Oleh karena itu, perlu dilakukan penelitian dan pengkajian tentang kiprah, peran, pemikirannya dalam bidang pendidikan.

Penelitian dan pengkajian ini dikhususkan dalam bidang pemikiran inovasi pendidikannya dengan dibatasi pada konsep dan peran dalam mewujudkan lembaga pendidikan; dan pemikirannya dalam pendidikan dan pengajaran. Akan tetapi, kalau penelitian ini juga mengungkap aktivitas-aktivitas TGR. Syekh 'Abdurrahman Ya'qub dakwah dan pemerintahan serta pengungkapan pemikiran-pemikiran keagamaannya, seperti pemikiran dalam aspek bahasa, hukum (fiqh), teologi (ilmu kalam), itu hanya dimaksudkan untuk melihat secara totalitas aspek-aspek intelektual figur ulama MelayuIndragiri ini.

Memperhatikan peran dan kiprah TGR. Syekh 'Abdurahmana Ya'qub pada umumnya, dan pemikiran pendidikannya pada khususnya di wilayah Indragiri, Riau memiliki sejumlah signifikansi (arti penting), sekaligus menjadi tujuan penelitian ini, yaitu: pertama, untuk mengungkapkan bahwa di kawasan Melayu-Indragiri pada paruh pertama abad ke-20 pernah hidup seorang ulama yang memiliki ilmu keagamaan yang otoritatif, komperhensif serta produktif. Artinya, penelitian ini, setidaknya, memiliki arti penting dan bertujuan untuk mengeleminir keterbatasan informasi dan kemiskinan pengetahuan tentang sosok TGR. Syekh 'Abdurrahman Ya'qub. Kedua, untuk menggambarkan peran dan kiprah TGR. Syekh 'Abdurrahman dalam bidang mengambangan lembaga pendidikan di Indragiri Hilir. Ketiga, untuk mengetahui pemikiran inovatif TGR. Syekh 'Abdurrhaman Ya'qub dalam bidang pendidikan dalam rangka pengembangan dan kemajuan pendidikan di Indragiri Hilir. 


\section{B. Biografi Tuan Guru Reteh (TGR) Syekh ‘Abdurrahman Ya'qub}

TGR. Syekh Abdurrahman Ya'kub dilahirkan dari ayah-ibu, Haji Ya'qub dan Hajjah Hafsah pada tanggal 12 Oktober 1912 (1331 H) di Desa Sungai Bangkar, Kecematan Reteh, Inderagiri. ${ }^{2}$ Nama “Abdurrahman” bukanlah nama yang diberikan sewaktu lahir, nama yang diberikan oleh orang tuanya adalah Mansur. Ketika ia menuntut ilmu di Mekkah nama Mansur tetap dipergunakan dengan tambahan nama orang tuanya, Rajab, sehingga nama lengkapnya adalah Mansur bin Rajab. Ia juga dikenal pula dengan nama penambahan yang dinisbatkan pada kampung halamannya, sehingga kadang dipanggil dengan nama Mansur Reteh Indragiri. Akan tetapi, setelah pulang dari Mekkah namanya diganti menjadi Abdurrahman, dan begitu pula nama orang tuanya berganti menjadi Ya'qub, sehingga ulama besar Reteh Indragiri ini bernama Abdurrahman Ya'qub. ${ }^{3}$

TGR. Syekh 'Abdurrahman Ya'qub, menurut salah seorang puteranya, bernama Kurdi, bahwa ayahnya semasa kecil diasuh dan dibesarkan oleh ayahnya, H. Ya'qub dengan menanamkan pendidikan agama dan penuh kasih sayang. Sejak kecil 'Abdurrahman sudah terlihat kecerdasan dan kemandiriannya, misalnya ketika ayahnya memberi tugas pelajaran, ia dapat selesaikan sendiri tanpa meminta bantuan kepada orang lain, kecuali jika ia rasakan tugas itu benar-benar sulit dan tidak mampu ia selesaikan. ${ }^{4}$ TGR. Syekh 'Abdurrahman Ya'qub diasuh dan dididik oleh orang tuanya dalam keadaan hidup sederhana dan penuh disiplin. Usaha yang dilakukan H. Ya‘qub mendidik dan mengasuh anaknya itu membuahkan hasil positif pada diri dan perilaku 'Abdurrahman setelah ia dewasa. ${ }^{5}$

Setalah tinggal beberapa lama di Desa Sungai Bangkar, Rajab membuka tempat tinggal baru yang belakangan dikenal dengan nama Parit Rajab. Nama Parit Rajab diadopsi dari namanya sendiri sebagai pertanda bahwa ia pertama kali membukanya sekaligus menjadi kepala paritnya. ${ }^{6}$ Dengan kedudukan dan wewenang sebagai sebagai pimpinan masyarakat, tentu status sosial dan ekonomi Rajab relatif cukup tinggi dan

${ }^{2}$ H. 'Abdurrahman Ya'qub, Nail al-Amani li Ma'rifah al-Auqat al-Syar'iyah (selanjutnya disingkat Nail al-Amani) (Bukittinggi: Nusantara, 1956), 3.

${ }^{3}$ H. Kurdi HAR, Wawancara, 25 Maret 2013 di Pasar Kembang. Kemudian, data wawancara ini diperkuat data dokumen. Lihat H. Kurdi HAR, Sejarah Berdirinya Madrasah Nurul Wathan, Dokumen (tidak diterbitkan).

${ }^{4}$ H. Kurdi HAR, Wawancara, 25 Maret 2013 di Pasar Kembang.

${ }_{5}^{5}$ Syafruddin Saleh (Cucu H. 'Abdurrahman Ya'qub), Wawancara, 25 Maret 2013 di Pekanbaru.

${ }^{6}$ Lihat, Ismail Chalid, Kenangan Tiga Zaman Bersama ABAH AR: Menggali Kembali Kenangan Masa Lalu (belum diterbitkan), 8. 
baik dibandingkan dengan masyarakat secara umum. Dengan status sosial dan ekonomi yang mapan semacam ini yang mengantarkan 'Abdurrahman bersama kedua orang tuanya, Ya'qub dan Hafsah serta adik kandungnya berangkat ke tanah suci Mekkah untuk menunaikan ibadah haji, ${ }^{7}$ dan sekaligus mengantarkan 'Abdurrahman belajar di kota suci Mekkah.

Latar belakang pendidikan 'Abdurrahman dapat dikatakan cukup tinggi untuk ukuran zamannya. Sebelum melanjutkan pendidikan di kota Mekkah, 'Abdurrahman menempuh pendidikan awalnya pada ayahnya sendiri, H. Ya'kub. Ayahnya sendiri sewaktu muda belajar agama Islam di Kedah Malaysia. Dengan pendidikan agamanya itu, sehingga ia dipandang sebagai tokoh agama dan tokoh masyarakat yang cukup berpengaruh dalam masyarakat. Sebagai tokoh agama, banyak orang datang belajar agama Islam terutama ilmu tauhid dan fiqh dengannya. ${ }^{8}$

Selain itu, H. Ya 'qub terkenal pula sebagai pedagang, ${ }^{9}$ ia banyak menghabiskan waktu bepergian ke luar daerah untuk membawa barang dagangannya. Karena kesibukan H. Ya'qub lebih banyak pada dunia perdagangan, akibatnya pendidikan anaknya tidak berjalan lancar. Melihat kondisi demikian ini H. Ya'qub mengambil inisiatif mengantarkan anaknya untuk penempuh pendidikan dasarnya ke Desa Teluk Dalam Sapat. Ayahnya menyerahkan anaknya kepada sejumlah guru untuk dibimbing dan bina, terutama meneruskan pendidikan agama yang sudah diajarkannya oleh ayahnya sebelumnya. ${ }^{10}$ Di Desa Teluk Dalam ini 'Abdurrahman menempuh pendidikan

\footnotetext{
${ }^{7}$ Kota Mekkah adalah suatu tempat yang dipandang suci oleh seluruh bangsa Arab dan umat Islam seluruh dunia. Mekkah tempat pusat berkumpul umat Islam seluruh dunia untuk menunaikan haji dan umrah, Mekkah dengan Masjid Haram yang di dalamnya terdapat Ka'bah sebagai kiblat umat Islam dalam melaksanakan ibadah shalat. Selain Mekkah sebagai pusat peribadatan umat Islam, Mekkah juga sebagai kota pelajar yang menjadi tumpuan umat Islam dari berbagai penjuru dunia datang ke sana untuk menuntut ilmu pengetahuan, khususnya ilmu pengetahuan agama Islam. Di kota suci inilah lahirnya Islam yang kemudian menyebar dan berkembang keseluruh penjuru dunia, termasuk Indonesia. Ulama yang hidup pada awal abad dua puluhan sampai sekarang banyak lulusan dari Timur Tengah khususnya Mekkah. Lihat Ahmad Syalabi, Sejarah Kebudayaan Islam, Jilid I (Jakarta, Pustaka Al-Husna, 1990).

${ }^{8}$ Lihat Hajar Hasan, Metode..., 35.

${ }^{9}$ Ulama dan tokoh masyarakat Indragiri Hilir yang hidup pada awal abad dua puluhan secara umum mempunyai perekonomian yang kuat. Ada ulama yang mempunyai kebun yang banyak, ada yang mempunyai usaha dagang, sehingga dalam mengembangkan dan menyebarkan Islam dengan berda'wah tidak membebani masyarakat dan pemerintah, bahkan sebagian hartanya disumbangkan untuk kepentingan agama dan keperluan masyarakat. Ulama pada waktu itu mempunyai ekonomi yang mapan, hidupnya tidak digaji oleh pemerintah. H. Ya'kub adalah tokoh masyarakat yang sangat dermawan dengan harta yang dimilikinhya.

${ }^{10}$ H. Zuhri adalah seorang guru mengaji dan ilmu fiqh yang terkenal di Teluk Dalam Sapat, beliau berasal dari suku Banjar yang hijrah dari Kalimantan Selatan ke Tembilahan dan menetap di Teluk Dalam. Sebelumnya, ia mendapat pendidikan agama Islam di tanah kelahirannya, Kalimantan Selatan. Lihat ibid.
} 
Zulkifli M. Nuh, Alimuddin Hassan, Kholil Syu'aib: Tuan Guru Reteh...

dasarnya dengan mengaji sekaligus belajar seni baca al-Qur`an dan materi dasar pendidikan tradisional Islam, seperti tafsir dan hadis, fiqh, tauhid dan ilmu falak di bawah asuhan dan bimbingan beberapa orang guru, yaitu Haji Zuhri, dan Ustaz Lahya. ${ }^{11}$

Selama berada di bawah asuhan dan bimbingan H. Zuhri, 'Abdurrahman belajar dengan tekun dan sungguh-sungguh serta mencurahkan perhatiannya dalam belajar membaca al-Qur'an. Pada waktu itu sudah terlihat kecerdasan 'Abdurrahman dalam menerima dan memahami pelajaran yang diberikan gurunya. Pada mulanya tempat belajar mengaji al-Qur`an dan agama di rumah $\mathrm{H}$. Zuhri, melihat santrinya terus bertambah jumlahnya, akhirnya $H$. Zuhri bersama masyarakat Teluk Dalam Sapat membangun surau (mushala) tempat santri belajar mengaji al-Qur`an dan ilmu agama. H. Zuhri adalah sahabat $\mathrm{H}$. Ya'qub, ia memiliki kemampuan yang handal dalam membaca al-Qur`an, dan menguasai ilmu agama Islam dengan baik dan mendalam. $\mathrm{H}$. Zuhri dipandang sebagai ulama dan qari' di Teluk Dalam Sapat. Syekh 'Abdurrahman Ya'qub juga disebutkan berguru dan belajar mengaji al-Qur`an dan agama dengan Ustazd Lahaya. Ia juga seorang guru mengaji al-Qur'an yang terkenal di Teluk Dalam Sapat. ${ }^{12}$

Ketika 'Abdurrahman beranjak berusia remaja - waktu itu berusia sekitar lima belas tahun dan dapat dikatakan masih berusia sangat muda - ia berencana menyunting puteri anak desa Teluk Dalam Sapat. Akan tetapi, keinginannya itu tidak menjadi kenyataan karena tidak mendapat restu dari kedua orang tuanya. Keberatan ayah dan ibunya disebabkan keduanya menginginkan anaknya melanjut pendidikannya. Bagi keduanya sangat menyangkan kalau anaknya tidak melanjutkan pendidikannya, apalagi melihat pada diri anaknya ada tanda-tanda kepintaran dan kecerdasan dan bakal menjadi anak yang berguna di kemudian hari.

Harapan dan maksud orang tuanya agar menerus pendidikan yang lebih tinggi itu diterima dan disambut baik oleh 'Abdurrahman seraya mengurungkan keinginannya untuk berumah-tangga. ${ }^{13}$ Kedua orang tuanya merasa bersyukur dan gembira atas kepatuhan dan keinginan anaknya untuk melanjutkan pendidikannya di Mekkah. Untuk

\footnotetext{
${ }^{11}$ Ibid., 36.

${ }^{12}$ Ustadz Lahaya adalah keturunan suku Bugis berasal dari Sulawesi Selatan. Tidak diketahui secara pasti latar belakang ia meninggalkan kampung halamannya untuk hijrah ke Tembilahan dan menetap di Teluk Dalam Sapat. Dengan begitu, tidak diketahui di mana ia menempuh pendidikannnya. Ia selain berkebun juga menjadi guru mengaji al-Qur`an, sehingga namanya cukup terkenal di Teluk Dalam Sapat.

${ }^{13}$ H. Khalid (Tokoh Agama), Wawancara, 27 Mei 2013 di Kota Baru.
} 
itu, pada tahun 1927 M. (1345 H.) 'Abdurrahman bersama orang tuanya berangkat ke tanah suci Mekah untuk menunaikan ibadah haji dan menuntut ilmu di Mekkah.

Tradisi menuntut ilmu di Haramain (kota Mekkah dan Madinah) pada waktu itu sudah mencapai puncaknya pada akhir-akhir abad ke-19. Bahwa dalam penelitian Snouck Hurgronje selama 6 bulam di Mekkah, jumlah mahasiswa Indonesia di sana mencapai lebih dari 5.000 orang, mewakili 50 persen dari seluruh mahasiswa asing di kota Mekkah dan Madinah. ${ }^{14}$ Dan tentu saja tradisi menuntut ilmu ini berlanjut memasuki dekade-dekade awal pada abad ke-20 seiring dengan banyaknya jumlah umat Islam Nusantara menunaikan ibadah haji yang, pada rentang waktu 1911-1914, mencapai puncaknya lebih 50 persen dari keseluruhan jamaah haji dari seluruh penjuru dunia Islam. Dengan demikian banyak sekali jamaah haji yang masih muda memanfaatkan kesempatan untuk tinggal beberapa tahun di kota Mekkah dan Madinah untuk melanjutkan dan memperdalam ilmu pengetahuan agama. Bahkan tidak sedikit di antara mereka menjadi 'ulama terkenal dan mengajar di dua kota suci ummat Islam itu. ${ }^{15}$

Pada awal kedatangannya di kota Mekkah, 'Abdurrahman Ya'qub mengikuti pengajian "halaqah" di Masjid Haram Mekkah dari ulama-ulama ternama. Dengan tetap mengikuti pengajian di Masjid al-Haram, 'Abdurrahman Ya'qub menempuh pendidikan formalnya di Madrasah Shaulatiyah. ${ }^{16}$ Ia masuk pada Madrasah Shaulatiyah dengan pertimbangan karena madrasah memiliki reputasi dan pengaruh besar bagi dunia pasantren di Indonesia pada akhir abad ke-19 dan awal abad ke-20. Banyak orang Indonesia yang pernah belajar di madrasah dan setelah pulang ke tanah air mendirikan madrasah atau pesantren dengan mengambil model pemebelajaran yang kurang lebih sama diterapkan di Madrasah Shaulatiyah. Perlu pula ditambahkan bahwa salah satu daya tarik madrasah ini sehingga banyak pelajar dari Indonesia menempuh pendidikan

\footnotetext{
${ }^{14}$ Lihat Zamakhsyari Dhofier, Tradisi Pesantren (Jakarta: LP3ES, 2011), 69-70.

${ }^{15}$ Ibid., 67-68.

${ }^{16}$ Pendirian Madrasah Shaulatiyah ini berawal dari seorang ini wanita India bernama Shaulah alNisa yang membiayai pembangunan madrasah dan mewakafkan tanah untuk pemeliharaannya. Kepemimpinan Madrasah Shaulatiyah dipercayakan kepada seorang ulama India militan dan hormati, Rahmatullah bin Khalil al-'Utsmani. Sewaktu masih di India Rahmatullah menjadi salah seorang pemimpin pemberontakan anti-Inggris pada 1857. Setelah pemberontakan itu dikalahkan Inggris, ia meninggalkan negerinya menuju ke Mekkah. Selama keberadaanya di Mekkah, ia tetap menjadi seorang ulama terkemuka yang sangat gigih melawan kolonialisme dan westernisme. Martin van Bruinessen, Kitab Kuning: Pesantren dan Tarekat (Bandung: Mizan, 1990), 35-36.
} 
Zulkifli M. Nuh, Alimuddin Hassan, Kholil Syu'aib: Tuan Guru Reteh...

di dalamnya karena guru-gurunya diambil dari ulama-ulama yang mengajar di Masjid al-Haram. ${ }^{17}$

'Abdurrahman Ya'qub menuntut ilmu pengetahuan di Madrasah Shaulatiyah selama kurang lebih 5 tahun. ${ }^{18}$ Namun tidak diketahui secara pasti apakah ia sempat menyelesaikan pendidikannya di madrasah ini; atau ia keluar bersama-sama dengan sejumlah pelajar Indonesia lainnya yang mencapai ratusan orang. Latar belakang keluarnya para pelajar Indonesia dari Madrasah Shaulatiyah dipicu karena konflik pemakaian bahasa Indonesia yang telah menyinggung kebanggaan nasional pelajar Indoensia. ${ }^{19}$ Untuk itu, orang-orang Indonesia di Mekkah "bergotong royong" mengumpulkan dana untuk membangun sekolah sendiri. Akhirnya, sekolah itu berdiri dengan nama Dar al-'Ulum al-Diniyah pada tahun 1934. Mayoritas pelajar Indonesia yang berasal dari Madrasah Shaulatiyah itu terdaftar sebagai pelajar pada Madrasah Dar al-'Ulum al-Diniyah yang baru didirikan itu. ${ }^{20}$

Abdurrahman Ya'qub sendiri telah menamatkan pendidikan menegahnya di Madrasah Shaulatiyah. 'Abdurrahman Ya'qub termasuk pelajar senior turut berperan aktif dalam pendiriaan Madrasah Dar al-'Ulum. Setelah berdirinya lembaga pendidikan Madrasah Dar al-'Ulum, sebagai salah sesorang pendiri bersama-sama dengan rekanrekan lainnya, 'Abdurrahman Ya'qub menjadi tenaga pengajar di lembaga itu pada pendidikan tingkat dasar. Selain itu menjadi tenaga pengajar, 'Abdurrahman Ya'qub juga melanjutkan pendidikan tingginya di Madrasah Dar al-'Ulum. ${ }^{21}$ Lembaga pendidikan dipimpin Madrasah Dar al-'Ulum diserahkan kepada salah seorang gurunya sewaktu belajar di Madrasah Shaulatiyah bernama Sayyid Muhsin bin 'Ali al-Musawa,

\footnotetext{
${ }^{17}$ Ibid.

${ }^{18}$ Lihat H. Kurdi HAR, "Sejarah..."

${ }^{19}$ Ada tiga riwayat dan pengamatan kemungkinan penyebab timbulnya konflik antara pelajar Indonesia dengan guru di Madrasah Shaulatiyah. Pertama, riwayat yang menyebutkan bahwa karena ada seorang guru merobek surat kabar berbahasa Indonesia yang sedang dibaca para murid. Tindakan guru itu boleh jadi benar karena didasarkan pada aturan bahwa bacaan lain selain kitab berabahasa Arab dilarang di madrasah tersebut. Kedua, riwayat lain mengatakan bahwa konflik itu disebabkan orang-orang Indonesia ingin bercakap-cakap dalam bahasa Indonesia, selain bahasa Arab, kepada guru-guru meraka. Sebuah fakta menyebutkan, ungkap Bruinessen, bahwa setidaknya sejak tahun 1860 bahasa Melayu merupakan bahasa kedua di Mekkah setelah bahasa Arab. Ketiga, riwayat ini berasal dari Syekh Yasin alPadani (Rektor Dar al-'Ulum) yang menyaksikan langsung konflik itu mengatakan (ketika diwawancarai oleh Bruinessen, 6 Maret 1988 di Jakarta) bahwa guru tersebut mengejek aspirasi nasionalisme orang Indonesia dengan mengatakan bahwa bangsa bodoh seperti itu tidak akan pernah bisa meraih kemerdekaan. Melihat sikap radikalisme pendiri Madrasah Shaulatiyah, boleh jadi guru-guru di madrasah ini telah mencemooh orang Indonesia yang kurang berani dan tegas berhadapan dengan penjajah Belanada. Lihat Martin van Bruinessen, Kitab Kuning...

${ }^{20}$ Ibid., 36-37.

${ }^{21}$ Lihat Hajar Hasan, Metode..., 37.
} 
seorang ulama terkemuka dari Palembang. Sayyid Muhsin mengangkat Syekh Muhammad 'Ali al-Maliki menjadi kepala Dewan Pengajar Madrasah Dar al-'Ulum. ${ }^{22}$ Sayyid Muhsin sebagai pimpinan bersama-sama dengan guru-guru lainnya mengembangkan dan memajukan madrasah tersebut. 'Abdurrahaman Ya'qub juga diberi kepercayaan mengajar di Masjid Haram Mekkah. Dengan demikian, selama keberadaannya di Mekkah, 'Abdurrahman memanfaatkan waktu dan kesempatannya untuk menggeluti dunia pendidikan dan pengajaran, yaitu belajar dan mengajar. ${ }^{23}$

Selama menetap dan belajar di Mekkah, baik di Masjid Haram, di Madrasah Shaulatiyah maupun di Madrasah Dar al-'Ulum, 'Abdurrahman Ya'qub mendapat bimbingan dan menimba ilmu keagamaan dari guru-gurunya yang sangat 'alim dan diakui keulamaannya. Di antara guru-guru 'Abdurrahman Ya'qub adalah: Syekh Muhammad 'Ali al-Maliki, ${ }^{24}$ Syekh Sayyid Hasan al-Masysyath, ${ }^{25}$ Sayyid Muhsin bin al-Musawa al-Falimbani, ${ }^{26}$ Syekh 'Umar Hamdan, ${ }^{27}$ Syekh Zubair, Syekh Muhammad Zen Boyan, Syekh Muhammad Sa'id Tungkal, Syekh 'Usman Muhammad Sa'id Tungkal, Syekh Sa‘id Yamani, Syekh Mahmud Bukhari, Syekh Abdul Hamid Amuntai,

\footnotetext{
${ }^{22}$ Lihat "Syaikh Muhammad Ali Al-Maliki: Menggeluti Ilmu tanpa Henti," dalam Al-Kisah..., 144.

${ }^{23}$ Lihat, Hajar Hasan, Metode...

${ }^{24}$ Nama lengkap ulama besar ini adalah Muhammad 'Ali bin Husain bin Ibrahim bin Husain bin "Abid al-Makki. Nama "laqab" di akhir namanya, yaitu "al-Maliki" dinisbatkan kepadanya setelah menjabat sebagai mufti Mazdhab Maliki menggantikan kakaknya, Syekh 'Abid al-Maliki pada 1921 di Mekkah. Beberapa tahun kemudian, beliau diangkat menjadi kepala Dewan Pengajar Madrasah Dar al'Ulum, Mekkah, sejak madrasah itu didirikan pada tahun 1934 oleh Sayyid Muhsin bin Ali al-Musawa, seorang ulama terkemuka kelahiran Palembang. Syekh Muhammad 'Ali dikenal sebagai Syaikh Masyayikh 'Ashrihi (Guru para Guru di Masanya). Beliau memiliki kealiman yang sangat luar biasa dalam bidang nahwu (tata bahasa/gramatika Arab), sehingga mendapat gelar "Sibawaihi Zamanih" (Sibawaih di Zamannya). Selain itu, Syekh Muhamamad "Ali begitu masyhur juga disebabkan kerena kepakarannya dalam berbagai disiplin keilmuan Islam; melahirkan banyak karya-karya; pengabdiannya dalam pendidikan dan pengajaran yang begitu lama; dan juga karena beliau memiliki banyak murid-murid yang datang dari berbagai penjuru dunia Islam, termasuk dari Indonesia. Guru besar para guru-guru, termasuk guru 'Abdurrahman Ya'qub ini, kembali ke rahmatullah pada tanggal, 28 Sya'ban 1368 (bertepatan dengan tanggal, 24 Juni 1949). Lihat, "Syaikh Muhammad Ali Al-Maliki: Menggeluti Ilmu tanpa Henti," dalam Al-Kisah..., 140-145.

${ }^{25}$ Syekh Hasan al-Masysyath adalah termasuk ulama besar yang pernah berguru pada Syekh Muhamamad 'Ali al-Maliki (wafat 1399 H./1989 M). Lihat, Al-Kisah, No. 24/17 - 30 November 2008, 141-142.

${ }^{26}$ Sayyid Muhsin, sebagaimana telah disebutkan di atas, adalah pendiri Madrasah Dar al-Ulum. Akan tetapi uniknya ia sekaligus ikut pula belajar kepada Syekh Muhammad Ali al-Maliki sebagai kepala Dewan Pengajar madrasah yang didirikannya itu. Lihat ibid., 144.

${ }^{27}$ Syekh 'Umar Hamdan adalah ulama besar semasa dengan Syaikh Muhammad Ali al-Maliki yang juga ahli hadis dan menjadi salah satu mata rantai terpenting dalam periwatan hadis. Lihat ibid., 145 .
} 
Syekh Ahmad Banat, Syekh Muhammad Yasin al-Padani, ${ }^{28}$ Muhammad Yunus, Ja'far Johor, Idris Jambi, dan lain-lain. ${ }^{29}$

Sewaktu menuntut ilmu di Mekkah, Abdurrahman memiliki teman-teman seperguruan, yang belakangan setelah Indonesia merdeka mereka memiliki jabatan dan kedudukan penting, di antara teman-temannya itu adalah Tuan Guru K.H. Muhammad Zainuddin Abdul Majid (pendiri Madrasah Nahdlatul Wathan, Pancor, NTB), K.H. Junaidi (Menteng Atas, Jakarta Selatan), ${ }^{30}$ dan juga Farid Ma'ruf ${ }^{31}$ dan Abdul Kahar Muzakkar yang kemudian melanjutan pendidikannya di Kairo, Mesir. ${ }^{32}$

Setelah menamatkan pendidikan tingkat tingginya di Madrasah Dar al-'Ulum, 'Abdurrahman Ya'qub mendapat kepercayaan untuk dapat menjadi muballigh ke negeri Jepang yang akan dipimpin oleh gurunya, Sayyid Muhsin bin 'Ali al-Musawa alFalimbani. Akan tetapi, tawaran tersebut ditolak oleh 'Abdurrahman Ya'qub dengan halus dengan alasan karena ia sendiri sebelumnya telah berketetapan hati ingin pulang ke tanah airnya. Bagi 'Abdurrahman Ya'qub berbakti kepada nusa bangsa jauh lebih berguna dan bermaafaat, khususnya mengabdi dan membina masyarakat di wilayah leluhurnya, Indragiri yang menunggu bimbingannya. ${ }^{33}$

Ia menuntut ilmu di Mekkah selama kurang lebih 12 tahun. Selama menetap di Mekkah, Syekh 'Abdurrahman Ya'qub berkenalan dengan Hj. Rugayah yang berasal dari daerah Merlung Jambi. Hj. Rugayah sudah sejak kecil menetap di Mekkah bersama orang tuanya. Perkenalan 'Abdurrahman Ya'qub dengan $\mathrm{Hj}$. Rugayah diikat dengan tali pertunangan dan berakhir dengan pernikahan. Pernikahan 'Abdurrahman Ya‘qub dengan Hj. Rugayah dilangsungkan pada tahun 1938 M/1356 H. di kota suci

\footnotetext{
${ }^{28}$ Ulama besar kelahiran Mekkah keturunannya berasal dari Padang Sumatra Barat ini adalah seorang pakar hadis yang sangat terkemuka. Dengan latar belakang pendidikan yang demikian beragam, ia memiliki "sanad" yang sangat banyak dalam berbagai ilmu dan kitab, karenanya ia digelari sebagai "Musnid al-Dunya" (Orang yang Memiliki Sanad Paling Banyak di Dunia). Lihat ibid., 141-142.

${ }^{29}$ H. Kurdi HAR, Sejarah....

${ }^{30}$ Lihat Al-Kisah..., 141-142.

${ }^{31}$ Farid Ma'ruf (dari Jawa) tidak saja menempuh pendidikan di Mekkah, tetapi, menurut William Roof, ia juga melanjutkan pendidikan tingginya di Cairo, Mesir. Sepulang dari Mesir, di Indonesia ia aktif dan menjadi pengurus di organisasi Muhammadiyah dengan menduduki jabatan di bagian pendidikan. Dalam skala lebih besar, Farid Ma'ruf pernah menduduki jabatan penting di Deparemen Agama (sekarang Kementerian Agama) sebagai Dirketur Jenderal Urusan Haji di awal tahun 1950-an. Beliau juga tercatat sebagai Guru Besar (Profesor) di Institut Agama Islam Negeri (IAIN) Syarif Hidayatullah, Jakarta. Lihat, William Roff, “Indonesian and Malay Student in Cairo in the 1920's”, dalam Indonesia, No. 9 (April) 1970, 81.

${ }^{32}$ Abdul Kahar Muzakkar, seperti beberapa pelajar Indonesia, juga melanjutkan pendidikan tingginya di Universitas al-Azhar, Mesir. Lihat, William Roff, "Indonesian...," 84-85.

${ }^{33}$ H. Kurdi (Putra Syaikh 'Abdurrahman Ya'qub) Wawancara, 27 Maret 2013 di Pasar Kembang; Lihat juga, Sejarah...
} 
Mekkah. ${ }^{34}$ Setelah menikah 'Abdurrahman Ya'qub bersama isterinya kembali ke Indonesia, tepatnya ke daerah Desa Teluk Dalam Sapat di Indragiri Hilir Riau, dan menetap di sana. Pada waktu itu ia bersama isterinya mulai mengajar dan mengembangkan ilmu yang dimilikinya kepada masyarakat.

Pada akhir tahun 1937, 'Abdurrahman Ya'qub bersama isterinya kembali ke tanah kelahirannya, yaitu di Desa Teluk Dalam Sapat. ${ }^{35} \mathrm{Di}$ desa inilah ia mulai mengembangkan ilmu pengetahuan yang diperolehnya selama dua belas tahun belajar di kota Mekkah, dengan cara mengajarkan ilmu tersebut kepada santri dan masyarakat luas. Sistem mengajar yang ia lakukan adalah dengan sistem halaqah dan tidak mempunyai tingkatan dan kelas. ${ }^{36}$ Kegiatan mengajar yang diasuh TGR. Syekh 'Abdurrahman Ya'qub tersebut berlangsung selama tiga tahun. ${ }^{37}$

Setelah menetap tiga tahun di Teluk Dalam Sapat, TGR. Syekh 'Abdurrahman Ya'qub pindak ke Enok. Di daerah ini ia mengajar dan aktif berdakwah, seperti yang dilakukannya di Teluk Dalam Sapat. Setelah lebih kurang tiga tahun mengajar dan berdakwah di Enok, ia kembali lagi ke Teluk Dalam Sapat atas permintaan masyarakat. Selama dua tahun ia menetap di Teluk Dalam Sapat, kemudian pada tahun 1946 M, ia pindah ke Kota Baru Reteh, Keritang Inderagiri Hilir.

Di Kota Baru, TGR. Syekh 'Abdurrahman Ya'qub diangkat menjadi pejabat agama (Kantor Urusan Agama pada masa sekarang). Pada tahun 1947 M beliau bersama masyarakat setempat mendirikan madrasah yang diberi nama Madrasah Nurul Wathan. Pada tahun 1949 M (lebih kurang berumur dua tahun) madrasah tersebut habis terbakar, dan masyarakat Kotabaru kehilangan lembaga pendidikan yang mereka banggakan. Kemudian pada tahun 1954 M. TGR. Syekh 'Abdurrahman Ya'qub. bersama masyarakat dengan penuh semangat kembali membangun madrasah dengan nama yang sama yaitu Madrasah Nurul Wathan, lokasinya yang baru di Desa Sungai Gergaji tidak

\footnotetext{
${ }^{34}$ Syartibi (Cucu H. 'Abdurrahman Ya'qub), Wawancara, 24 Mei 2013 di Pekanbaru.

${ }^{35}$ Menurut Penuturan H. Kurdi bahwa sewaktu Syekh 'Abdurrahman menuntut ilmu di Mekkah beliau dikenal dengan nama Mansur Rajab. Namun, ketika mau turun "ke bahwah angin" (pulang ke tanah air), beliau mengganti namanya menjadi, sebagaimana yang masyhur sekarang, yaitu $\mathrm{H}$. 'Abdurrahman Ya'qub. H. Kurdi (Putra Syaikh 'Abdurrahman Ya'qub) Wawancara, 27 Maret 2013 di Pasar Kembang; Lihat, “K.H. Abd. Rahman Ya'kub (1907-1970) Pendiri Pesantren Nurul Wathan, Dokumen tidak diterbitkan.

${ }^{36}$ Sistem pendidikan dan pengajaran halaqah yang diterapkan H. 'Abdurrahman Ya'qub ada dua hal. Pertama, mengacu kepada sistem yang berlaku di Mekkah, karena rata-rata pendidikan di Mekkah pada masa itu dengan sistem halaqah. Kedua, karena belum tersedia sarana pendidikan di desa Teluk Dalam Safat seperti Madrasah.

${ }^{37}$ Sartibi (cucu H. 'Abdurrahman Ya'qub), Wawancara, 24 Maret 2013 di Pekanbaru.
} 
Zulkifli M. Nuh, Alimuddin Hassan, Kholil Syu'aib: Tuan Guru Reteh...

berapa jauh dari lokasi madrasah yang lama. Pimpinan madrasah langsung dipercayakan kepada TGR. Syekh 'Abdurrahman Ya'qub. ${ }^{38}$

Madrasah Nurul Wathan banyak melahirkan lulusan yang meneruskan pendidikan ke tingkat perguruan tinggi, di dalam maupun di luar negeri. Waktu dan tenaga TGR. Syekh 'Abdurrahman Ya'qub banyak dicurahkan mengajar di madrasah ini, di samping itu beliau aktif memberi pengajian dan berdakwah di tengah masyarakat luas. Ia mengembangkan ajaran Islam melalui dunia pendidikan, memberikan ceramah agama dalam berbagai kesempatan, berda'wah ke masyarakat luas dan menulis dalam berbagai cabang ilmu seperti fikih, tauhid, bahasa arab, ilmu falak dan lainnya. Berdasarkan pengetahuan agama yang dikuasainya, ia dipandang sebagai ulama yang kharismatik, dilihat dari ketekunan dan kesungguhanya dalam duani pendidikan ia ditetapkan masyarakat sebagai tokoh pendidikan dan karena kiprahnya di tengah masyarakat, beliau diangkat sebagai tokoh masyarakat.

Salah satu tanda kebesaran seorang ulama pada masa dahulu dapat ditelusuri dari karya-karya tulis yang dihasilkannya. Kalau benar demikian, melihat produktivitasnya dalam melahirkan karya-karya tulis berupa buku-buku, maka TGR. Syekh Abdurrhaman Ya'qub sangat layak disebut sebagai ulama besar. Menulis buku bukanlah perkerjaan mudah, selain memerlukan kekayaaan materi dan khazanah ilmu pengetahuan, juga memerlukan waktu dan perhatian serius. Akan halnya TGR. Syekh 'Abdurrahman Ya'qub, di samping kesibukannya dalam melaksanakan tugas sebagai da'i (penyeru dakwah) dan guru (pendidik dan pengajar), ia masih dapat menyisihkan sebagian waktunya untuk belajar dan menulis. ${ }^{39}$

TGR. Syekh 'Abdurrahman Ya'qub dapat dikatakan tergolong penulis yang produktif yang telah melahirkan sejumlah karya tulis berupa kitab/buku dalam disiplin ilmu yang berbeda-beda. TGR. Syekh Abdurrahman Ya'qub telah menulis sejumlah kitab dalam berbagai disiplin keilmuan agama, seperti bahasa Arab, tauhid, fikih, ilmu waris dan ilmu falak. Menurut Hajar Hasan dari hasil wawancaranya dengan Kurdi, putra TGR. Syekh 'Abdurrahman Ya'qub, menyebutkan bahwa kitab yang ditulis ayahndanya terdapat puluhan kitab banyaknya, tetapi yang ada hanya tinggal enam buah

\footnotetext{
${ }^{38}$ Madrasah Nurul Wathan yang didirikan oleh H. 'Abdurrahman Ya'qub bersama masyarakat Kota Baru sampai sekarang masih terpelihara. Madrasah yang memiliki tingkat Tsanawiyah dan tingkat Aliyah cukup berkembang di bawah pimpinan anaknya, H. Kurdi.

${ }^{39}$ Hajar Hasan, Metode..., 44.
} 
kitab. Kitab-kitab tersebut sebagian besar tidak dapat ditemukan sekarang karena musnah sewaktu Madrasah Nurul Wathan terbakar. Meskipun demikian, karya-karya tulis TGR. Syekh 'Abdurrahman Ya'qub yang dapat dijumpai hanya enam kitab, empat sudah dicetak dan dua buah dalam bentuk naskah. Menurut anak dan cucunya, karya TGR. Syekh 'Abdurrahman Ya'qub sebagian dicetak dan diterbitkan di percetakan Nusantara Bukittinggi dan sebagiannya lagi dicetak dan diterbitkan di Singapura. ${ }^{40} \mathrm{Di}$ antara karya-karya tulis TGR. Syekh 'Abdurrahman Ya'qub berupa kitab yang masih dapat dijumpai adalah (1) Amsilah al-Mukhtasar (tentang bahasa Arab); (2) Qawa id an-Nahwiyyah (tentang tata bahasa Arab); (3) Ahwal al-Waratsah fi Taqsim at-Tirkah (tentang ilmu faraidh); (4) Nail al-Amani li Ma'rifah al-Auqat al-Syar'iyah (tentang ilmu falak); (5) Kitab Fiqh (masih berbentuk naskah dan belum diterbitkan); dan (6) Kitab Tauhid (masih berbentuk naskah dan belum diterbitkan). ${ }^{41}$

Selain itu, TGR. Syekh Abdurrahman Ya'qub juga menciptakan lagu, yaitu: tiga berbahasa Arab; dan 12 lagu berbahasa Indonesia. Misalnya Murid Nurul Wathan, Kami Pemuda Islam, Wahai Kawan, 27 Rajab, Maulid Nabi, dan lain-lain. Lagu-lagu gubahan Syekh Abdurrahman Ya'qub dipelajari dan dinyanyikan di sejumlah madrasah di Indragiri, terutama di madrasah yang ada di Kecamatan Keritang, Kecematan Reteh, Kecematan Tanah Merah dan Enok. ${ }^{42}$

\section{Kiprah dan Perannya dalam Bidang Pendidikan}

Adapun aktifitas pendidikan dan pengajaran, sebagaimana disebutkan sebelumnya, telah digeluti TGR. Syekh 'Abdurrahman Ya'qub semasih tinggal di Mekkah. Maka setelah menamatkan pendidikannya, TGR. Syekh 'Abdurrahman Ya'qub memulai mengembangkan ilmu pengetahuan yang diperolehnya di tanah kelahirannya, dengan cara mengajarkan ilmu tersebut kepada pelajar dan masyarakat luas. Pada mulanya sistem pendidikan dan mengajar yang lakukan oleh TGR. Syekh 'Abdurrahman Ya'qub adalah sistem halaqah yang tidak mempunyai tingkatan dan kelas. Ia menerapkan sistem halaqah ini dengan mengacu sistem halaqah yang berlaku di Mekkah disebabkan belum tersedianya sarana pendidikan dan pengajaran di Desa

\footnotetext{
${ }^{40}$ Ibid.

${ }^{41}$ Harun al-Rasyid (guru Madrasah Nurul Wathan), Wawancara, 28 Maret 2013 di Pasar Kembang, Keritang.

${ }^{42}$ Lihat, Kurdi HAR, Riwayat Ringkas Almarhum H. Abdurrahman bin H. Ya'kub, Dokumen belum diterbitkan.
} 
Zulkifli M. Nuh, Alimuddin Hassan, Kholil Syu'aib: Tuan Guru Reteh...

Teluk Dalam Sapat, seperti madrasah. Kegiatan mengajar yang diasuh TGR. Syekh 'Abdurrahman Ya'qub tersebut berlangsung selama tiga tahun. Pada masa ini pula, melihat minat dan perhatianya yang sungguh besar dalam bidang pendidikan dan pengajaran, TGR. Syekh 'Abdurrahman Ya'qub diminta Tuan Guru Syekh 'Abdurrahman Shiddiq, atas nama kerajaan Inderagiri, untuk mengajarkan ilmu-ilmu agama, yaitu hadis, fikih, akidah, tasawuf, bahasa Arab dan ilmu falak. ${ }^{43}$ Permintaan Syekh 'Abdurrahman Shiddiq kepada TGR. Syekh 'Abdurrahman Ya'qub ini mengindikasikan pengakuan langsung atas kedalaman ilmunya dalam berbagai disiplin.

Belakangan, sepeninggalan Tuan Guru Syekh 'Abdurrahman Shiddiq pada 1940, Syekh 'Abdurrahman Ya'qub pindah dan menetap beberapa tahun di Enok. Setelah menetap satu tahun di Enok, TGR. Syekh 'Abdurrahman Ya'qub bersama masyarakat setempat membangun sebuah lembaga pendidikan, yaitu madrasah dengan nama "Dar al-Ta 'lim" pada tahun $1941 \mathrm{M} / 1361 \mathrm{H}$. Pada sekolah ini terdapat bangunan asrama untuk menampung para pelajar yang datang dari luar Enok. Dengan berdirinya lembaga pendidikan agama pertama di Enok, daerah ini menjadi terkenal dan banyak pelajar yang datang dari luar dalam rangka belajar di madrasah tersebut. Daerah Enok ketika itu menjadi pusat perhatian masyarakat sebagai tempat pendidikan agama. ${ }^{44}$

Setalah keberadaanya di Enok dan kemudian kembali lagi di kampung halamannya selama kurang lebih dua tahun, TGR. Syekh 'Abdurrahman Ya'qub bersama keluarganya pindah ke Sungai Gergaji, Keritang pada tahun 1946. Di daerah baru ini ia melakukan kegiatan yang sama, sebagaimana didomisili sebelumnya, yaitu mengajar dan berdakwah serta menjadi pembimbing dan "obor penerang" masyarakat. Tidak lama berselang keberadaannya di Sungai Gergaji, TGR. Syekh 'Abdurrahman Ya'qub bersama masyarakat di Sungai Gergaji beerhasil mendirikan madrasah yang diberi nama madrasah "Nurul Wathan." Sayangnya, madrasah yang dibangun tersebut terbakar sampai habis, teramsuk sejumlah buku hasil karangannya. Berdasarkan semangat dan keinginan yang kuat dari masyarakat di bawah arahan dan bimbingan TGR. Syekh 'Abdurrahman Ya'qub madrasah tersebut dibangun kembali di lokasi yang berbeda dengan nama yang tetap sama pada tahun $1954 .{ }^{45}$ Dari tahun ke tahun Madrasah Nurul Watan terus mengalami perkembangan dan kemajuan yang sangat

\footnotetext{
${ }^{43}$ Ibid

${ }^{44}$ Hajar Hasan, Metode..., 42.

${ }^{45}$ Ibid.
} 
signifikan baik dari segi kuantitas santri dan guru maupun dari segi kualitas akademiknya. Para santri setiap tahun terus bertambah, konsekuensinya gurupun harus bertambah. Untuk mengatasi kesejahteraan para guru TGR. Syekh 'Abdurrahman Ya'qub sendiri dengan kedermawanan yang dilandasi kerelaan dan keikhlasan menginfakkan sebagian hartanya, selain ditambah dengan bantuan masyarakat dan sumbangan dari wali santri yang disesuaikan dengan kemampuan ekonomi mereka. ${ }^{46}$

Sistem penerimaan santri di Madrasah Nurul Wathan dilakukan seleksi atau diadakan tes penempatan. Tujuan dari tes semcam ini dimaksudkan untuk mengetahui kemampuan santri dan sekaligus menentukan tingkatan mereka. Santri yang lulus tes langsung diterima dan ditempatkan pada tingkat Ibtidaiyah. Sementara siswa yang tidak lulus dilakukan pembinaan dengan diberikan materi martikulasi selama satu tahun (menjelang masuknya pada tahun depan). ${ }^{47}$

Sistem pendidikan yang diberlakukan di Madrasah Nūrul Wathan sudah diubah dari halaqah (tanpa kelas dan tingkatan), menjadi sistem kelas dan tingkatan. Dengan perubahan sistem itu, madrasah ini menjadi tumpuan masyarakat memasukan anak-anak mereka sebagai santri di madrasah tersebut.

Belakangan, TGR. Syekh 'Abdurrahman Ya'qub pindah ke Desa Pasar Kembang, letaknya tidak jauh dari Desa Sungai Gergaji pada 1966 m/1387 H. Ketika TGR. Syekh 'Abdurrahman Ya'qub tinggal di Desa Pasar Kembang, kesehatannya mulai menurun dan selalu sakit. Akan tetapi, TGR. Syekh 'Abdurrahman Ya'qub tetap memiliki tekad yang kuat, tidak luntur dan surut sedikitpun untuk tetap mengembangkan pendidikan dan menyiarkan agama Islam. Upaya TGR. Syekh 'Abdurrahaman Ya'qub bersama-sama masyarakat dalam bidang pendidikan terbukti, misalnya, mampu mendirikan lembaga pendidikan di Desa Pasar Kembang. Namun, sangat disayangkan, TGR. Syekh 'Abdurrahman Ya'qub tidak sempat melihat perkembangan dan kemajuan madrasah yang telah bangunnya tersebut, lantaran ulama kharismatik yang sangat dihormati, disegani dan dimuliakan masyarakat itu dipanggil oleh Allah swt pada tanggal 15 April 1970 M bersamaan dengan tanggal 6 Sya‘ban 1391 H. di Pasar Kembang, Keritang, Indragiri Hilir. ${ }^{48}$

\footnotetext{
${ }^{46}$ Ibid.

${ }^{47}$ Ibid

${ }^{48}$ Sebelum TGR. Syekh Abdurrahman Ya'kub menghembuskan nafas terakhir ia sempat melaksanakan salat Zuhur, zikir dan berdo'a, kemudian beliau memangil anak-anaknya untuk dibaringkan. Sekitar sepuluh menit setelah itu, dalam keadaan tenang beliau menghembuskan nafasnya yang terakhir. Maisyarah (anak H.Abdurrahman Ya'kub), Wawancara, 27 Maret 2013 di Pasar Sungai Kembang.
} 
Zulkifli M. Nuh, Alimuddin Hassan, Kholil Syu'aib: Tuan Guru Reteh...

Menelaah dan melihat perjalanan hidup dan kiprah TGR. Syekh 'Abdurrahman Ya'qub dalam mengembangkan ajaran Islam, khususnya dalam dunia pendidikan maka beliau sangat tepat dikatakan seorang ulama yang mempunyai kemampuan dan kesungguhan luar biasa menggeluti dunia pendidikan. Sebagai ulama, TGR. Syekh 'Abdurrahman Ya'qub membimbing dan mengajak umat mengamalkan ajaran Islam. Kehadirannya sebagai ulama membawa kedamaian dan kesejukan dalam masyarakat, karena semua masalah agama yang dihadapi masyarakat dapat diselesaikannya dengan baik. Sebagai tokoh masyarakat kharismatik ia dikagumi dan disayangi oleh lapisan masyarakat. Sosok TGR. Syekh 'Abdurrahman Ya'qub tidak ada duanya baik pada masanya maupun sekarang, karena TGR. Syekh 'Abdurrahman Ya'qub mempunyai kesungguhan luar biasa dalam menegakkan ajaran Islam di mana saja beliau berada.

\section{Pemikiran Inovatif dalam Bidang Pendidikan}

Inovasi TGR. Syekh 'Abdurrahman Ya'qub di bidang kurikulum pendidikan dan pengajaran, sebagaimana dikemukakan oleh Ismail C.H dalam tulisannya: "Belum lama setelah ABAH AR berdomisili di Kotabaru Reteh, di samping beliau berkiprah menangani urusan dinas keagamaan, di sini beliau mendirikan sebuah lembaga pendidikan agama, untuk sarana pengembangan ilmu pengetahuan agama Islam bagi penduduk negeri. Di samping itu juga sebagai usaha awal dalam merintis pengenalan bahasa Arab terhadap para pelajar Islam di wilayah ini dan sekitarnyayang pada masa sebelumnya belum pernah diadakan. Untuk tujuan tersebut, maka buku-buku pelajaran yang diajarkan di madrasah ini, yang seratus persen pelajaran agama itu, seluruhnya berbahasa Arab. Madrasah yang dibangun ABAH AR, atas bantuan masyarakat setempat itu, berdiri tanggal 27 Nopember 1947, sebuah bangunan berdinding papan terdiri dari dua lokal. Madrasah tersebut diberi nama 'NURUL WATHAN', artinya Cahaya Negeri. Untuk membedakannya dengan Sekolah Rakyat Negeri, yang sudah berdiri sejak dahulu, maka madrasah ini lebih dikenal dengan sebutan 'Sekolah Arab'.,49

Dengan demikian, Madrasah Nurul Wathan yang didirikan dan diasuh langsung oleh TGR. Syekh Abdurrahman Ya'qub tersebut hanya mengajarkan ilmu agama Islam dengan sumber kajian atau mata pelajarannya adalah kitab-kitab yang ditulis atau

\footnotetext{
${ }^{49}$ Ismail Chalid, Kenangan..., 15
} 
berbahasa Arab. Secara garis besar mata pelajaran tersebut mencakup al-Qur`an beserta tajwid dan tafsirnya, hadis dan mushthalahnya, 'aqa'id, fiqh dan ushul fiqh, bahasa Arab dengan seperangkat ilmu alatnya, tarikh, dan manthiq. Ditambah satu mata pelajaran umum, yaitu ilmu hisab.

Kitab-kitab yang dipelajari dibedakan menjadi dua tingkatan, yaitu tingkat dasar dan tingkat lanjutan. Setiap siswa harus dipastikan menguasai kitab-kitab pada tingkat dasar terlebih dahulu, baru boleh mempelajari kitab-kitab pada tingkat lanjut.

\section{Tabel 1. Kurikulum dan Kitab-kitab Pelajaran Dasar TGR. Syekh 'Abdurrahman Ya'qub}

\begin{tabular}{|c|c|c|c|}
\hline No & Pelajaran & Nama Kitab & Pengarang \\
\hline 1 & Tauhid & Matan Sanusiyah & $\begin{array}{l}\text { Al-Imam Abu 'Abd Allah } \\
\text { Muhammad ibn Muhammad ibn } \\
\text { Yusuf al-Sanusi }\end{array}$ \\
\hline 2 & Fiqh & Safinatun Naja & $\begin{array}{l}\text { Al-Syaikh Salim ibn 'Abd Allah } \\
\text { ibn Sumair }\end{array}$ \\
\hline 3 & Tajwid & Hidayatul Mustafid & Muhammad Mahmud \\
\hline 4 & Nahwu & Matan Jurumiyah & $\begin{array}{l}\text { Muhammad ibn Dawud al- } \\
\text { Shanhaji }\end{array}$ \\
\hline 5 & Sharaf & Matan Bina & Mulla 'Abd Allah al-Danqary \\
\hline 6 & Akhlak & $\begin{array}{l}\text { Al-Akhlaq li al- } \\
\text { Banin/Banat }\end{array}$ & 'Umar ibn Ahmad Baraja' \\
\hline 7 & Bahasa Arab & - & - \\
\hline 8 & Khat & - & - \\
\hline 9 & Nazham & - & - \\
\hline
\end{tabular}

Mata-mata pelajaran ini diberikan pada kelas I, II, dan III tingkat dasar Madrasah Nurul Wathan. Pada kelas I, materi pelajaran yang diberikan guru dari kitabkitab yang tersebut di atas wajib dihafal oleh para siswa, sewaktu-waktu hafalan mereka akan diperiksa.

Pada kelas II, materi-materi pelajaran tersebut dari kitab-kitab itu diberi makna perkata yang ditulis dengan Arab Melayu. Biasanya teks-teks pelajaran tersebut ditulis oleh guru di papan tulis disertai dengan makna setiap kata yang ditulis miring tepat di bawah kata yang dimaksud. Setiap siswa harus mengetahui makna dari setiap materi pelajaran, sewaktu-waktu para siswa harus memperdengarkannya di hadapan guru.

Berbeda ketika di kelas II, di kelas III materi-materi pelajaran tersebut diterangkan oleh guru dengan uraian secara luas, sehingga dapat dipahami oleh para siswa dengan sebaik-sebaiknya. Sewaktu-waktu para siswa diminta untuk menerangkan 
Zulkifli M. Nuh, Alimuddin Hassan, Kholil Syu'aib: Tuan Guru Reteh...

pelajaran yang telah diajarkan di hadapan guru, guru dan para murid yang lain menyimak keterangan dari murid yang bersangkutan, sembari memberikan perbaikanperbaikan jika terdapat kesalahan.

Setelah para siswa menyelesaikan pelajaran pada tingkat dasar, pelajaranpelajaran tersebut ditingkatkan kepada yang lebih tinggi, dengan memilih kitab-kitab yang lebih tinggi tingkatannya. Jika pada tingkat dasar kitab-kitab pelajaran berupa matan yang singkat, pada tingkat lanjut, kitab-kitab pelajarannya berupa kitab syarah (keterangan) dan atau hasyiyah (komentar) dari kitab-kitab pelajaran sebelumnya. Mata pelajaran yang diajarkan pada tingkat lanjut dapat dilihat pada tabel berikut:

Tabel 2. Kurikulum dan Kitab-kitab Pelajaran Lanjutan TGR. Syekh ‘Abdurrahman Ya'qub

\begin{tabular}{|c|c|c|c|}
\hline No & Mata Pelajaran & Nama Kitab & Pengarang \\
\hline 1 & Al-Tafsir & $\begin{array}{l}\text { Tafsir al-Qurian al- } \\
\text { Karim (Tafsir } \\
\text { Jalalain) }\end{array}$ & $\begin{array}{l}\text { Al-Imam Jalal al-Din al-Mahalli } \\
\text { Al-Imam Jalal al-Din al-Suyuthi }\end{array}$ \\
\hline 2 & Al-Hadits & $\begin{array}{l}\text { Muwaththa al-Imam } \\
\text { Malik }\end{array}$ & Al-Imam Malik \\
\hline 3 & Al-Tauhid & $\begin{array}{l}\text { Hasyiyah 'ala Matn } \\
\text { al-Sanusiyah }\end{array}$ & Al-Syaikh Ibrahim al-Baijuri \\
\hline 4 & Al-Fiqh & Fath al-Qarib & $\begin{array}{l}\text { Al-Syaikh Muhammad ibn } \\
\text { Qasim al-Ghazzi }\end{array}$ \\
\hline 5 & Ushul al-Fiqh & Al-Waraqat & Al-Imam al-Juwaini \\
\hline 6 & Al-Nahwu & Syarh Ibn 'Aqil & $\begin{array}{l}\text { Al-Syaikh 'Abd Allah ibn 'Abd } \\
\text { al-Rahman ibn 'Aqil }\end{array}$ \\
\hline 7 & Al-Sharf & $\begin{array}{l}\text { Syarhani 'ala Marah } \\
\text { al-Arwah fi 'Ilm al- } \\
\text { Sharf }\end{array}$ & Ahmad ibn 'Ali ibn Mas'ud \\
\hline 8 & $\begin{array}{l}\text { Mushthalah al- } \\
\text { Hadits }\end{array}$ & Thal'ah al-Anwar & $\begin{array}{l}\text { Sidi 'Abd Allah ibn al-Hajj } \\
\text { Ibrahim al-'Alawi al-Syinqithi }\end{array}$ \\
\hline 9 & Ushul al-Tafsir & Nahj al-Taisir & Sayyid Muhsin al-Musawi \\
\hline 10 & Al-Manthiq & Idhah al-Mubham & Ahmad al-Damanhuri \\
\hline 11 & Al-Bayan & $\begin{array}{ll}\text { Hasyiyah 'ala al- } \\
\text { Risalah } \\
\text { Samarqandiyah }\end{array}$ & Ibrahim al-Baijuri \\
\hline 12 & Al-Tarikh & $\begin{array}{l}\text { Nur al-Yaqin fi Sirah } \\
\text { Sayyid al-Mursalin }\end{array}$ & $\begin{array}{l}\text { Al-Syaikh Muhammad } \\
\text { Khudhari Bik }\end{array}$ \\
\hline $\begin{array}{l}13 \\
14\end{array}$ & $\begin{array}{l}\text { Fara idh } \\
\text { 'Ilm al-Migat }\end{array}$ & $\begin{array}{l}\text { Matn Al-Rahbiyah } \\
\text { Taarib al-Maashad }\end{array}$ & Al-Imam al-Rahbi \\
\hline
\end{tabular}

Selain mata pelajaran sebagaimana disebutkan di atas, terdapat pula mata pelajaran tambahan yang wajib dipelajari oleh murid, yaitu barzanji, ilmu hisab, dan 
muhadharah (berpidato). Mata pelajaran yang disebutkan terakhir ini menjadi penekanan khusus, karena tidak mengherankan jika murid Madrasah Nurul Wathan tersebut pada level (tingkat) lanjut ini sudah mampu berkhutbah. ${ }^{50}$

Mata-mata pelajaran ini diajarkan pada kelas IV, V, dan VI. Tingkatan kelas ini disesuaikan dengan materi pelajaran yang terdapat dalam kitab-kitab pelajaran tersebut. Sistem pengajarannya, para siswa menyimak bacaan guru lalu memberikan harakat (baris) pada kitab, jika kitab pelajaran yang bersangkutan tidak berharakat. Para siswa juga memperhatikan keterangan yang disampaikan oleh guru, lalu memberikan catatancatatan penting pada bagian pinggir kitab-kitab pelajaran, baik berupa makna kata-kata (mufradat) maupun keterangan-keterangan penting lainnya.

Tingkatan akhir dari Madrasah Nurul Wathan adalah kelas VII. Para siswa kelas akhir ini dipersiapkan untuk dapat mengajarkan kitab-kitab yang telah mereka pelajari. Bahkan mereka sudah diminta untuk mengajar kelas-kelas di bawahnya. Di antara mereka ada yang dipercaya oleh TGR. Syekh Abdurrahman Ya'qub menjadi guru bantu, karena jumlah siswa di Madrasah Nurul Wathan kian bertambah.

Materi dan silabus masing-masing pelajaran yang diajarkan TGR. Syekh 'Abdurrahman Ya'qub terfokus kepada pokok bahasan yang ada dalam kitab-kitab yang diajarkan. Materi dan silabus bagi masing-masing mata pelajaran di atas merupakan ilmu dasar yang harus dikuasai oleh setiap murid, baik untuk pengamalan ajaran agama dalam keseharian yang termasuk fardhu 'ain, maupun sebagai prasyarat untuk mempelajari ilmu-ilmu atau kitab-kitab yang akan dipelajari pada tingkat lanjutan. Kesulitan murid dalam menguasai materi-materi dalam kitab-kitab lanjutan akan terantisipasi jika penguasaan terhadap materi-materi dasar tersebut baik.

Bekaitan dengan metode pendidikan dan pengajaran, salah satu metode pendidikan dan pengajaran yang diterapkan oleh TGR. Syekh Abdurrahman Ya'qub adalah metode halaqah. Metode ini beliau gunakan ketika mengajar di Teluk Dalam Sapat pada tahun 1938, atas penugasan dari Mufti Kerajaan Indragiri, Syekh 'Abdurrahman Shiddiq. ${ }^{51}$ Kondisi ini beliau lakukan karena belum terdapat sarana pendidikan, sehingga beliau memanfaatkan masjid dan rumah kediaman sebagai tempat belajar.

\footnotetext{
${ }^{50}$ H. Moehammad Junus, “Catatan Pribadi”; dan Wawancara tanggal 27 September 2013

${ }^{51}$ H. Kurdi HAR, Sejarah...
} 
Zulkifli M. Nuh, Alimuddin Hassan, Kholil Syu'aib: Tuan Guru Reteh...

Pada tahun 1945 beliau pindah ke Kotabaru Reteh. Di tempat ini beliau menyempatkan untuk mengajar, walaupun dalam keadaan suasana waktu itu masih belum aman. Dalam hal ini beliau memanfaatkan rumah untuk belajar, dengan metode belajar membentuk halaqah. Karena murid kian bertambah maka belaiu memutuskan untuk mendirikan sebuah lokal untuk tempat belajar. Inilah awal berdirinya Madrasah Nurul Wathan pada tahun $1947 .^{52}$

Setelah Madrasah Nurul Wathan berjalan pun belajar dengan metode halaqah masih rutin dilakukan oleh TGR. Syekh 'Abdurrahman Ya'qub. Sebagaimana dikemukakan oleh Ismail C.H. dalam tulisannya, bahwa TGR. Syekh 'Abdurrahman Ya'qub memanfaatkan ruang tamu rumah beliau untuk mengajar mata pelajaran Pengantar Ilmu Faraidh setiap malam Selasa, sebagai pelajaran tambahan yang tidak diberikan di kelas. ${ }^{53}$

Metode ini beliau adopsi dari model pendidikan di Masjid al-Haram Mekah, tempat beliau menimba banyak ilmu dari para guru beliau. Di mana semua murid mengelilingi gurunya, masing-masing murid mendengarkan apa yang disampaikan oleh guru (syekh). Adapun materi halaqah di Masjid al-Haram tersebut, seperti tafsir, hadis, fiqh dan ushul fiqh. Sebagian murid membawa kitab, dan sebagian lagi hanya pendengar setia. Murid-murid yang belajar pada masyayikh di Masjid al-Haram berasal dari berbagai negara, seperti Indonesia, Malaysia, India, Pakistan, Afrika, dan sebagian lagi daratan Jazirah Arab.

Selain metode halaqah, TGR. Syekh Abdurrahman Ya'qub juga menerapkan metode klasikal, sebagaimana dilakukan di Madrasah Darut Ta'lim Enok dan Madrasah Nurul Wathan Kotabaru Reteh. ${ }^{54}$ Kegiatan belajar di Madrasah Nurul Wathan pada masa itu terbagi kepada dua kelompok; kelompok yang masuk pagi hari dan kelompok siang (petang). Para siswa yang masuk di pagi hari terdiri dari pelajar putra semua. Usia mereka heterogen (tidak satu level). Ada yang masih pra-remaja, ada yang sudah remaja, dan ada pula beberapa orang di antaranya yang sudah memasuki usia dewasa. Sedangkan para siswa yang masuk siang, mereka adalah sampuran putera dan puteri. Hampir semua mereka terdiri dari murid-murid Sekolah Rakyat (SR) - kini disebut Sekolah Dasar (SD) - kelas II dan kelas III.

\footnotetext{
${ }^{52}$ Lihat K.H. Abd. Rahman Ya'qub..., 1-2

${ }^{53}$ Lihat Ismail C.H. Kenangan..., 18

${ }^{54}$ H. Kurdi HAR, Sejarah...
} 
Pelajaran dimulai jam 07.00 sampai jam 09.30, tanpa istirahat. Kelas siang dimulai jam 2 siang sampai jam 4.30, juga tanpa istirahat. Baik kelas pagi maupun kelas siang diajar langsung oleh TGR. Syekh 'Abdurrahman Ya'qub. Kelak pada pertengahan tahun 1948, tugas-tugas TGR. Syekh 'Abdurrahman Ya'qub di madrasah diserahkan kepada Guru Ahmad Manshur, sebagai guru pengganti beliau di Madrasah Nurul Wathan.

Metode klasikal juga diambil TGR. Syekh Abdurrahman Ya'qub model pendidikan di Madrasah Dar al-'Ulum Mekah, juga tempat beliau memperoleh banyak pelajaran dari para masyayikh. Di Mekah, kendati para pelajar belajar dengan cara klasik (halaqah), mereka juga belajar model pendidikan klasikal (formal education). Di Mekah, ada beberapa sekolah yang menerapkan model ini, seperti Madrasah Dar al'Ulum al-Diniyah (didirikan oleh Syekh Mohammad Yasin al-Fadani), Madrasah Shaulatiyah, dan Madrasal al-Falah.

Di Masjid al-Haram sendiri sebagian murid yang mengikuti halaqah, ternyata banyak juga yang ikut serta dalam pendidikan formal, di Ma'had Al-Haram. Ma'had ini termasuk pendidikan formal, letaknya di pintu Malik Fahd bin 'Abd al-'Aziz. Pelajarpelajar dari berbagai negara, seperti Indonesia, Afrika, India, Pakistan, Thailand, Malaysia diterima belajar di sana. Bahkan, tidak sedikit dari warga Negara Arab Saudi sendiri yang ikut belajar di Ma'had al-Haram. Tentunya setelah melalui seleksi yang ketat serta mengikuti aturan dan ketentuan-ketentuan yang telah disepakati oleh kerajaan. Pelajar-pelajarnya juga mendapat bantuan (beasiswa) setiap bulan dari pemerintah. Materi yang diajarkan adalah ilmu agama, karena tujuan utamanya ialah melestarikan nilai al-Qur'an, sunnah Nabi SAW., dan kitab-kitab klasik.

\section{E. Kesimpulan}

TGR. Syekh 'Abdurrahman Ya'qub termasuk ulama produktif dalam melahirkan karya tulis, dengan karya tulis itu beliau dapat menyampaikan pemahaman dan pemikiran keagamaan secara leluasa kepada masyarakat. Ia disebut sebagai ulama yang memiliki ilmu keagamaan yang otoritatif, komprehensif, dan produktif di kawasan Melayu-Indragiri dan kawasan Melayu Riau. Ia telah memainkan kiprah dan peran sangat penting, utama, dan ganda di tengah masyarakat, terutama dalam bidang pendidikan. 
Zulkifli M. Nuh, Alimuddin Hassan, Kholil Syu'aib: Tuan Guru Reteh...

\section{F. Daftar Pustaka}

Abdullah, Syafei. Riwayat Hidup dan Perjuangan Ulama Syekh H. Abdurrahman Shiddiq, Mufti Indragiri. Jakarta: Serajaya, 1984.

Abdulah, Taufik, \& Sharon S.(ed.). Tradisi dan Kembangkitan Islam Asia Tenggara. Jakarta: LP3ES, 1988.

Haji, Raja Ali. Bustan al-Katibin li Subyani Muta 'allim. Pulau Penyengat: Yayasan Kebudayaan Indra Sakti, Koleksi Naskah No. 19, 1983

Andaya, Barbar W. dan Virginia Matheson. "Islamic Thougth and Malay Tradition Writing of Raja Ali Haji of Riau." Perceptions of The Past in Southeast Asia, ed. Anthony Reid dan David Marr. Singapura: Heineman Education Book [Asia] Ltd., 1979

Azra, Azyumardi. Jaringan Ulama Timur Tengah dan Kepuulauan Nusantra Abad XVII dan XVIII. Bandung: Mizan, 1995.

"Melacak Pengaruh dan Pergesaran Orientasi Tamatan Kairo." Studia Islmica, II, 3, (1995).

Bruinessen, Martin van. Kitab Kuning: Pesantren dan Tarekat. Bandung: Mizan, 1990.

Departemen Agama R.I. Almanak Hisab dan Rukyat. Jakarta: Badan Peradilan Agama, t.t.

Departemen Agama RI. Pedoman Penentuan Arah Kiblat. Jakarta: Direktorat Jenderal Pembinaan Kelembagaan Islam Direktorat Pembinaan Badan Peradilan Agama Islam, 1994/1995.

Dhofier, Zamakhsyari. Tradisi Pesanatren. Jakarta: LP3ES, 2011.

Effendy Hs, Imara. Pemikiran Akhlak Syekh Abdurrahman Shiddiq al-Banjari. Pekanbaru: LPNU Press, 2003.

Grunebaum, Gustave E. Von. Islam Kesatuan Dalam Keragaman. Jakarta: Yayasan Perhidmatan, 1983.

Hamidy, U.U. Potensi Lembaga Pendidikan Islam di Riau. Pekanbaru: UIR Press, 1994.

Hasan, Hajar. "Metode Penetapan Arah Kiblat, Waktu Shalat dan Awal Bulan Qamariyah Menurut H. 'Abdurrahman Ya'qub.” Disertasi. UIN Suska Riau, 2011.

Hasan, Muhammad Tholhah. Wawasan Umum Ahlussunnah Wal Jama'ah. Jakarta: Lantabora, 2006.

Iskandar, Teuku. Kamus Dewan. Kuala Lumpur: Dewan Bahasa dan Pustaka Kementerian Pelajar, 1970.

Marlow, Louise. Masyarakat Egaliter Visi Islam. Bandung: Mizan, 1999.

Moeliono, Anton M. (ed.). Kamus Besar Bahasa Indonesia. Jakarta: Balai Pustaka, 1988.

Nazir, M. Sisi Kalam Dalam Pemikiran Islam Syekh Abdurrahman Shidiq. Pekanbaru: Susqa Press, 1992. 
Noer, Deliar. Gerakan Modern Islam di Indonesia 1900-1942. Jakarta: LP3S, 1996.

Riddell, Petter. Islam and the Malay Indonesia World. Singapura: Horizon Books, 2001.

Roff, William. "Indonesian and Malay Student in Cairo in the 1920's." Indonesia, No. 9, April 1970.

Steenbrink, Karel A. Beberapa Aspek Tentang Islam di Indonesia Abad ke-19. Jakarta: Bulan Bintang, 1984.

Syihata, Abdullah. Al-Dakwah al-Islamiyah. Jakarta: Direktorat Jenderal Pembinaan Kelembagaan Agama Islam, 1986.

Syalabi, Ahmad. Sejarah Kebudayaan Islam. Jakarta, Pustaka Al-Husna, 1990. Jilid I

Tim Al-Kisah. "Syaikh Muhammad Ali Al-Maliki: Menggeluti Ilmu tanpa Henti." AlKisah, No. 24/17 - 30 November 2008

Ya'qub, Abdurrahman. Nayl al-Amani li Ma'rifah al-Auqat al-Syar'iyah, Bukittinggi: Nusantara, 1956.

Yusuf, Ahmad, dkk. Sejarah Kesultanan Indragiri. Pekanbaru: Pemda Riau, 1994. 